\title{
El legado de Jorge Charum en la Ciencia de Colombia
}

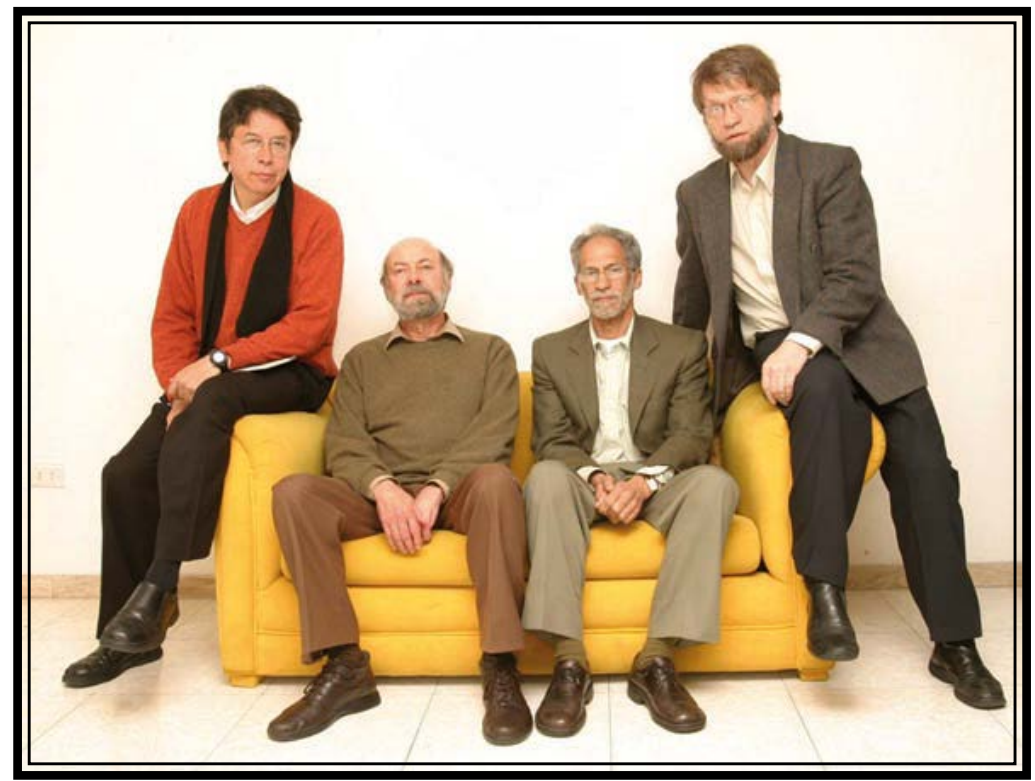

De izquierda a derecha: Carlos Augusto Hernández, José Granés, Jorge Charum y Antanas Mockus. Fotografía tomada de: http://historico.unperiodico.unal.edu.co/ediciones/96/06.html

El científico colombiano Jorge Charum ejerció un rol fundamental en el desarrollo de las bases conceptuales del Sistema Nacional de Ciencia, Tecnología e Innovación del país, e investigó sobre las formas para producir información de calidad para orientar a la política pública.

Charum se interesó en la diáspora científica y se trazó como objetivo crear una red de investigadores colombianos en el exterior, para fortalecer la ciencia del país y aprovechar al máximo el capital humano, impulsando así los Grupos y Centros de Investigación.

Además, Charum enfocó sus investigaciones en los sistemas de información, la bibliometría, la medición de la capacidad científica y su impacto en la sociedad. En 1999 propuso las bases de un sistema de información para grupos y centros que se utilizó en las convocatorias de Colciencias hasta 2004.

Así mismo, participó en las bases conceptuales del Sistema Nacional de Indexación y Homologación de Publicaciones Seriadas de CTeI - Publindex y en la creación del Observatorio Colombiano de Ciencia y Tecnología.

Desde Colciencias expresamos nuestra solidaridad a sus familiares y amigos cercanos por su fallecimiento. Su legado es invaluable y quedará grabado en la memoria de la ciencia colombiana.

Diego Andrés Chavarro C. Colciencias 